\title{
Rethinking Environmental Law Enforcement in Nigeria
}

\author{
Hakeem Ijaiya, 0. T. Joseph \\ Department of Private and Property Law, Faculty of Law, University of Ilorin, Nigeria \\ Email: hakeemijaiya@yahoo.com, hakeemijaiya@mail.com, buzeejozeea@yahoo.com
}

Received 24 September 2014; revised 12 November 2014; accepted 26 November 2014

Copyright (C) 2014 by authors and Scientific Research Publishing Inc.

This work is licensed under the Creative Commons Attribution International License (CC BY). http://creativecommons.org/licenses/by/4.0/

(c) (i) Open Access

\section{Abstract}

Environmental degradation has continued to generate unpleasant challenges for health and economic development in Nigeria. Some of these problems include deforestation, pollution, global warming and improper pesticides. Despite environmental laws and policies targeted at ameliorating these problems, the situation in Nigeria seems degenerating owing to the fact that these laws are not effectively enforced. This paper analyzes the use of environmental laws by different enforcement agencies in Nigeria, the methods of enforcement these agencies invoke, and the challenges they face in enforcing the relevant laws. These challenges include low-level constitutional provision for environmental protection, roles and conflicts in environmental management, undue adherence to legalism by the courts and absence of mandatory disclosure of information. Thus, the legislative objectives remain unachieved because enforcement is superficial; excessive time exists between non-compliance and enforcement; available punishment for non-compliance is inadequate; injured parties are not properly compensated; and some environmental crimes receive administrative instead of remedial measures or criminal punishments. The study advocates for the encouragement of private and public interest litigation, creation of procedure for enhancing public participation in Nigerian environmental protection, creation of environmental emergencies and establishment of environmental courts.

\section{Keywords}

Environments, Environmental Protection, Environmental Agencies

\section{Introduction}

The essence of a good environment can never be over-emphasised. The interdependency of man with or within 
the ecosystem is fundamental to human existence (Okorodudu-Fubara, 1998). Biblically, it can be perceived that God ensured that a good environment was created for mankind even before the creation of mankind ${ }^{1}$. Without this, man might possibly not have been created. The environment constitutes a basic necessity which was put in a good condition for mankind to explore, maintain and use for sustenance.

It is common to have things done excessively where there are no rules and regulations. Environmental laws are put in place to mitigate the threatening environmental problems which emanate from human activities in the quest for economic growth and development. The need for environmental control arises from the fact that it brings improved health and better living conditions (Adelagan, 2004). Legal checks and balances are imposed on mankind's present activities, to prevent the upcoming generations from suffering for present generation's reckless environmental damaging activities.

However, the major environmental problems in Nigeria which include oil spillage, deforestation and associated soil erosion, ozone layer depletion, desertification, acid deposition, global warming, oil pollution amongst others $^{2}$ arise as a result of the ineffective enforcement of environmental laws (Egbon \& Behrooz, 1996). This ineffectiveness is ascribed to some challenges of enforcement which ranges from role conflicts in environmental management, corruption and bad governance prevalent in the country to inadequate enforcement facilities.

It is on this background that this paper seeks to examine the nature of the environment, environmental problems, the evolution of environmental laws in Nigeria, the enforcement of environmental laws, the challenges faced by the enforcement agents in enforcing these laws, the deficiencies of the environmental laws and suggest possible reforms for effective enforcement of the environmental laws in Nigeria.

\section{The Development of Environmental Laws in Nigeria}

The development of Nigerian environmental laws can be divided into two:

1) The pre 1988 era

2) The post 1988 era

\subsection{The Pre 1988 Era}

During the colonial era, Nigeria was not concerned about the protection of the environment; it was not a priority. Accordingly, there was no policy aimed at preserving and protecting it (Ladan, 2009). The tort of nuisance was more prominent because disputes in environmental law were not viewed as public matters warranting state intervention. The few environmentally related laws that were applicable criminalized activities that could degrade the environment.

One of the laws was the Criminal Code Act of 1916, which prohibited water pollution and air pollution. In 1917, the Public Health Act was enacted. Although, somewhat broad in scope, this Act did not contain provisions of relevance to the regulation of land, air and water pollution. At this time, matters relating to the environment were dealt with in a rudimentary manner, from the view point of environmental sanitation (Otu, 2010).

Following Nigeria's independence in 1960 and the discovery of oil in commercial quantities, laws dealing with the environment obviously became grossly inadequate. This was owing to the fact that most of the provisions on environmental protection were scattered throughout different laws, resulting in ad-hoc response to different needs in different situations. During the decade following independence, the Government criminalized polluting activities, particularly those relating to the discharge of oil in navigable waters and environmental degradation as a result of petroleum activities.

The 1970s saw the further development of the Nigeria's environmental regime in response to the individual growth associated with the oil boom. River basin authorities ${ }^{3}$ were created and environmental units were established in some government ministries. The laws were, however, typically "knee-jerk" responses to emergency situations.

\footnotetext{
${ }^{1}$ See Genesis 1 verse 24, the Holy Bible.

${ }^{2}$ Increase in pollution of surface and ground water, inadequate water supply, coastal water erosion, marine pollution, electronic waste, air pollution, urban industrial pollution, oil pollution, indiscriminate dumping of refuse sewage and industrial wastes in the nation's streams and seas, improper use of pesticides and chemical fertilizers, noise pollution, over-grazing and over-fishing.

${ }^{3}$ River Basin Development Authority Act, 1987.
} 


\subsection{Post 1988 Era}

It is pertinent to note that the incidence of dumping toxic and hazardous wastes in Nigeria woke the Federal Government up to confront the problem of environmental abuse. This happened on the $19^{\text {th }}$ September 1987 when Sunday Oyemire Nana, a farmer in Koko, a small village five kilometers from the coast in the former Bendel State of Nigeria, was approached by Gian Franco Raffaelli, an Italian business man who had resided in Nigeria for some 20 years, to dump about 3880 tons of toxic and hazardous waste on behalf of an Italian company.

The Italian ship was discovered in May 1988. It was made up principally of polychlorobiphenyls (PCBS). However, the hostile media reaction that accompanied the discovery propelled the Federal Government of Nigeria to reassess the general state of its environmental regulation. This hastened the creation of Harmful Waste (Special Criminal Provision etc) Decree ${ }^{4}$ and the then Federal Environmental Protection Agency (FEPA). Hence, in December 1988, as part of the emerging coordinated approach to environmental issues, FEPA was established by decree ${ }^{5}$.

The Harmful Waste Act prohibits, without lawful authority, the carrying, dumping or depositing of harmful wastes in the air, land or waters of Nigeria 6 .

The Federal Environmental Protection Agency (FEPA) protects, restores and preserves the ecosystem of the Federal Republic of Nigeria ${ }^{7}$. The decree 58 of 1988 requires FEPA to establish environmental guidelines and standards for the abatement and control of all forms of pollution (Adelagan, 2004).

FEPA also had the power to initiate policy in relation to environmental research and technology and in formulating and implementing policies related to environmental management. In addition, FEPA was given some enforcement powers including the right to inspect facilities and premises, search locations, seize items and arrest people contravening any laws on environmental standards and prosecuting them.

The agency was also empowered to initiate specific programmes of environmental protection and establish monitoring stations or networks to locate sources of and dangers associated with pollution. It also has powers to conduct public investigations or enquiries into aspects of pollution.

FEPA (now National Environmental Standards and Regulations Enforcement Agency ${ }^{8}$ is presently the supreme reference authority in environmental matters in Nigeria although state and local government authorities and institutions including their environmental departments are still expected to play their traditional role of maintaining and enforcing standards as well as fixing penalties charges, taxes and incentives to achieve certain environmental goals.

With the setting up of FEPA, the States Environmental Protection Agencies (SEPAS) ${ }^{9}$ were set up. These were complemented by the Local Governments (LGAs) Environmental Protection Agencies.

The 1980 and 1990s witnessed the most drastic and systematic development of environmental laws in Nigeria, partly owing to Nigeria's subscription to a number of international conventions and treaties ${ }^{10}$ during this period. Legislations on environmental development improved during this period; we had various Nigerian legislations on the environment ${ }^{11}$ and some of them are still in operation today.

\section{Provisions of Some Environmental Laws and Regulations in Nigeria}

Environmental laws are worthless except they are effectively enforced. However, the functions of environmental laws should be well understood for effective and efficient enforcement. In Nigeria, environmental laws have been formulated and are being implemented to:

1) deal with a variety of environmental pollutions such as toxic chemicals, noise and others,

\footnotetext{
${ }^{4}$ Decree 42 of 1988.

${ }^{5}$ Decree 58 of 1988 .

${ }^{6}$ Section 6 of the Harmful Waste (Special Criminal Provisions) Act, CapH1 LFN 2004 provides for a punishment for life or life imprisonment for offenders as well as the forfeiture of land or anything used to commit the offence.

${ }^{7}$ Decree 58 of 1988 .

${ }^{8}$ National Environmental Standards and Regulations Enforcement Agency (Establishment) Act, 2007 replaced FEPA Act, 1988.

${ }^{9}$ Kwara State Environmental Protection Agency Act, Cap K16 Laws of Kwara State, 1992 is an example.

${ }^{10}$ Stockholm Declaration on the Human Environment, 1972.

${ }^{11}$ Environmental Law Research Institute Synopsis of Laws and Regulations on the Environment in Nigeria "Environmental law and policies in Nigeria”. <http://www.elri-ng.org/newsandrelease2.html>. Accessed on 02 January 2014.
} 
2) control particular activities such as mining, power generation, and

3) provide general guidelines for protecting basic natural resources such as water, air, land etc (Nwafor, 2006).

The responsibility for the enforcement of the various environmental protection laws does not lie with one specific body or organ of government, for instance, the responsibility for enforcement of the pre and post 1988 laws formally lie with the overseeing ministry (e.g. Forestry Act under Ministry of agriculture is enforced by Forest Rangers, The Public Health Act is enforced by Public Health Inspector etc.) while the regular law enforcement agents come in where a criminal offence is involved.

However, since the adoption of the National Policy on the environment in 1989 and the enactment of more comprehensive environmental protection laws and regulation, the enforcement of environmental protection laws in the country has assumed a more enhanced institutional

Some Federal Environmental Legislations.

\subsection{The 1999 Constitution of the Federal Republic of Nigeria}

The Constitution which is the supreme law of Nigeria recognizes the importance of improving and protecting the environment and makes provision for it. Section $\mathbf{2 0}{ }^{12}$ makes it an objective of the Nigerian state to improve and protect the air, land, water, forest and wild life of Nigeria.

Section 12 establishes impliedly that international treaties (including environmental treaties) ratified by the National Assembly should be implemented as law in Nigeria.

Sections 33 and 34 which guarantee fundamental human rights to life and human dignity respectively have also been argued to be linked to the need for a healthy environment to give these rights effects ${ }^{13}$.

\subsection{National Environmental Standards and Regulations Enforcement Agency (NESREA) Act 2007}

This Act replaced the Federal Environmental Protection Agency Act (FEPA), 1988. It is administered by the Federal Ministry of Environment to protect and promote the sustainable development of the environment and its natural resources. It is also referred to as "the agency". It is the major federal body charged with the protection of Nigeria's environment. It is an embodiment of laws and regulations focused on the protection and development of the environment, conservation and sustainable development of Nigeria's natural resources as well as environmental technology.

It provides authority to ensure compliance with environmental laws, local and international, on environmental sanitation and pollution prevention and control through monitory and regulatory measures ${ }^{14}$.

The agency makes and reviews regulations on air and water quality, effluent limitations, control of harmful substances and other forms of environmental pollution and sanitation ${ }^{15}$.

The agency also prohibits, without lawful authority, the discharge of hazardous substances into the environment ${ }^{16}$.

There are different regulations under NESREA:

1) National Effluent Limitation Regulation which requires industry facilities to have anti-pollution equipment for the treatment of effluent.

2) National Environment Protection (Pollution Abatement in Industries and Facilities Producing Waste) Regulations (1991) which prevents the release of hazardous substances into the air, land or water of Nigeria beyond approved limits set by the Agency.

3) Federal Solid and Hazardous Waste Management Regulations (1991)

This act compels industries to identify solid hazardous wastes which are dangerous to public health and the environment and to research into the possibility of recycling them.

\footnotetext{
${ }^{12}$ Constitution of the Federal Republic of Nigeria 1999, Cap 24, LFN 2004.

${ }^{13}$ Environmental Law Research Institute Synopsis of Laws and Regulations on the Environment in Nigeria "Environmental law and policies in Nigeria" < http://www.elri-ng.org/newsandrelease2.html > . Accessed on 02, January 2014.

${ }^{14}$ See Section 7 of the 2007 National Environmental Standards and Regulation Enforcement Agency (NESREA) Act.

${ }^{15}$ See Section 8(1) (k) of the 2007 NESREA Act.

${ }^{16}$ See Section 27 of the 2007 NESREA Act.
} 


\subsection{Environmental Impact Assessment Act 199217}

This act assesses the potential negative impacts public or private projects are likely to have on the environment ${ }^{18}$. However, it ensures written applications are submitted to the agency before embarking on projects for their environmental assessment to determine approval ${ }^{19}$. It also creates a legal liability for contravention of any provision ${ }^{20}$.

\subsection{Harmful Waste (Special Criminal Provisions) Act $1988^{21}$}

Since the koko incident, the dumping of harmful wastes in Nigeria has been prohibited. This act prohibits, without lawful authority, the carrying, dumping or depositing of harmful wastes in the air, land or waters of Nigeria $^{22}$. It also makes provisions for punishment of life imprisonment for offenders as well as the forfeiture of land or anything used to commit the offence ${ }^{23}$. Offenders are also liable to persons who have suffered injury as a result of his offending act.

\subsection{Oil Pipelines Act $1956^{24}$}

This act creates a civil liability on the person who owns or is in charge of an oil pipeline. Such a person would be held liable to pay compensation to anyone who suffers physical or economic injury as a result of a break or leak in his pipelines.

\subsection{Petroleum Act 196925}

This is the primary legislation on oil and gas activities in Nigeria. It ensures public safety and environmental protection ${ }^{26}$. There are three basic regulations under the Petroleum Act. They are:

1) Petroleum Drilling and Production regulations which places restrictions on licensees from using land within fifty yards of any building, prohibits the cut down of trees in forest reserves and establishes that reasonable measures be taken to prevent water pollution and to end it, if it occurs.

2) Petroleum Refining Regulation which requires the manager of a refinery to take measures to prevent and control pollution of the environment.

3) Mineral Oil Safety Regulations and Crude Oil Transportation and Shipment Regulations which provide that precautions should be taken in the production, loading, transfer and storage of petroleum products to prevent environmental pollution.

\subsection{Niger-Delta Development Commission (NDDC) Act ${ }^{27}$}

This act is concerned with using allocated fund to tackle ecological problems arising from the exploration of oil minerals in the Niger-Delta. The act ${ }^{28}$ empowers the commission to plan and to implement projects for the sustainable development of the Delta in the field of transportation, health, agriculture, fisheries, urban and housing development, etc. The commission under this act, has a duty to liaise with oil and gas companies and advice stakeholders on the control of oil spillages, gas flaring and other related forms of environmental pollution.

Other laws include; Land Use Act $1978^{29}$, Hydrocarbon Oil Refineries Act ${ }^{30}$, Associated Gas re-injection Act

\footnotetext{
${ }^{17}$ Environmental Impact Assessment Act, Cap E12 LFN 2004.

${ }^{18}$ See Section 2(1) EIA Act, Cap E12, LFN 2004.

${ }^{19}$ See Section 2(4) EIA Act, Cap E12, LFN 2004.

${ }^{20}$ See Section 60 EIA Act, Cap E12, LFN 2004.

${ }^{21}$ Harmful waste (Special Criminal Provisions) Act, Cap H1 LFN 2004.

${ }^{22}$ Section 6 of the Harmful Waste (Special Criminal Provisions) Act, CapH1 LFN 2004 provides for a punishment for life or life imprisonment for offenders as well as the forfeiture of land or anything used to commit the offence.

${ }^{23}$ See Section 6, Harmful Waste (Special Criminal Provisions) Act, Cap H1, LFN 2004

${ }^{24}$ Oil Pipelines Act, Cap 07 LFN 2004.

${ }^{25}$ Petroleum Act, Cap P10 LFN 2004.

${ }^{26}$ Environmental Law Research Institute Synopsis of Laws and Regulations on the Environment in Nigeria "Environmental law and policies in Nigeria” < http://www.elri-ng.org/newsandrelease2.html> . Accessed on 02 January 2014.

${ }^{27}$ Niger-Delta Development Commission (NDDC) Act, Cap N68 LFN 2004.

${ }^{28}$ See Section 7(1) (b) of the NDDC Act, Cap N68, LFN 2004.

${ }^{29}$ Land Use Act, Cap 202, LFN 2004 the Governor ensures proper allocation of lands in order to avoid misuse of land. This prevents the allocation of land in a residential area for persons who would use it for industrial purposes.

${ }^{30}$ Hydrocarbon Oil Refineries Act, Cap H5 LFN 2004 this act prohibits any unlicensed refinery of hydrocarbon oils in places other than a refinery and also requires refineries to maintain pollution prevention facilities.
} 
$1979^{31}$, The Endangered Species Act ${ }^{32}$, Sea Fisheries Act $1992^{33}$, Exclusive Economic Zone Act $1978^{34}$, Petroleum Products and Distributions (Management Board) Act ${ }^{35}$, Territorial Waters Act $1967^{36}$, Nuclear Safety and Radiation Protection Act ${ }^{37}$, Nigerian Mining Corporation Act ${ }^{38}$, Quarantine Act $1969^{39}$.

Some States Environmental Legislations

Each of the 36 States of Nigeria and the Federal Capital Territory of Abuja has laws dealing with environmental protection and safety. Under the State laws, enforcement is placed in the hands of several bodies which include; Environmental Sanitation Task Force, Waste Management Boards, State Environmental Protection Agencies, Environmental Sanitation Courts, Special Courts are also established to try any person who violates the laws. We shall focus on Lagos State and Kwara State.

The Lagos State government enacted the Environmental Sanitation Law and Environmental Pollution Control law on environmental pollution and protection.

\subsection{Environmental Sanitation Law of Lagos State}

This is a Lagos State enactment on environmental sanitation and protection. It prevents street obstruction, improper disposal of wastes, refusal to cover refuse bins and failure to clean sidewalks ${ }^{40}$.

\subsection{Environmental Pollution Control of Lagos State}

This law ${ }^{41}$ makes it an offence to cause or permit a discharge of raw untreated human waste into any public drain or water course or onto any land or water.

The Kwara State Government in order to create environmental awareness in the state enacted the Kwara State Environmental Protection Agency Law.

\subsection{Kwara State Environmental Protection Agency Law ${ }^{42}$}

This agency carries out research and development activity for environmental protection and to educate the general public on the types of disposal methods acceptable by the State Government for domestic and industrial wastes among others (Ijaiya, 2013).

\section{Enforcement Mechanisms}

The environmental protection laws at the Federal and State levels in Nigeria provide for impressive array of enforcement mechanisms. They include ${ }^{43}$ : permit, licence, certificate, inspection, search, seizure, arrest, sealing, notice of violation, notice of revocation of permit, revocation order, recourse to courts for civil penalties for violation, injunctive relief to require compliance, criminal sanctions for violations, citizen's suits to enforce the

\footnotetext{
${ }^{31}$ Associated Gas Re-injection Act, Cap 20 LFN 2004 this act prohibits without lawful permission, any oil and gas company from flaring gas in Nigeria.

${ }^{32}$ The Endangered Species Act, Cap E9 LFN 2004 focuses on the protection and management of Nigeria's wildlife and some other species, either presently or likely to be in danger of extinction.

${ }^{33}$ Sea Fisheries Act, Cap S4 LFN 2004 this act makes it illegal to take or harm fishes within Nigerian waters by use of explosives, poisonous or noxious substances.

${ }^{34}$ Exclusive Economic Zone Act, Cap E11 LFN 2004 this act prevents the exploit of natural resources within the exclusive zone without lawful authority.

${ }^{35}$ Petroleum Products and Distribution Act, Cap P12 LFN 2004 this act provides authority to make regulations for the protection of the environment from the harmful effects of ionizing radiation.

${ }^{36}$ Territorial Waters Act, Cap T5 LFN 2004.

${ }^{37}$ Nuclear Safety and Radiation Protection Act, Cap N142 LFN 2004.

${ }^{38}$ Nigerian Mining Corporation Act, Cap N120 LFN 2004 this act establishes the Nigerian Mining Corporation and it has the authority to engage in mining refining activities and to construct and maintain roads, dams, reservoirs.

${ }^{39}$ Quarantine Act, Cap Q2 LFN 2004.

${ }^{40}$ Environmental Law Research Institute Synopsis of Laws and Regulations on the Environment in Nigeria "Environmental law and policies in Nigeria" $<$ http://www.elri-ng.org/newsandrelease2.html> . Accessed on 02 January 2014.

${ }^{41}$ See Section 12 of the Environmental Pollution Control of Lagos State.

${ }^{42}$ Cap K16 Laws of Kwara State, 1992.

${ }^{43}$ See Sections 25 - 30, FEPA Decree, 1988; Sections 6, 10 - 12 Harmful Wastes Decree, 1984; National Environmental Protection (Effluent Limitations) Regulations 1991; National Environmental Protection (Pollution Abatement in Industries and Facilities Generating Wastes) Regulations 1991; National Environmental Protection Management of Solid and Hazardous Wastes Regulations 1991; and Environmental Impact Assessment Decree, 1992.
} 
statutes in the absence of effective government enforcement.

\subsection{Inspection and Searches}

The main purpose of inspection is to ensure that the laws applicable to individuals, industries and companies are obeyed. This is one of the most important enforcement methodologies; it also helps to know who has violated environmental laws in order to be able to take legal actions against such persons.

Authorized officers are empowered to request for and examine any mandatory licence, permit, certificate or other document, as well as any appliance, device or other items used in relation to environmental protection.

The power to search is always employed where there is suspected violation of the law. For example, under NESREA $^{44}$, where an authorized officer has a reasonable ground to believe that an offence has been committed contrary to the decree or any regulations made there under, he may without a warrant enter and search any land, building, vehicle, tent, vessel, floating craft or any inland water or other structure whatsoever, in which he has reason to believe that an offence against the decree or any regulations made there under has been committed.

However, there problems of "fake" inspectors who impersonate as officials or agency of NESREA and other institutions who are responsible for enforcement of the existing laws. It is suggested that the issue of fake officials can be reduced if uniform; badges and identity cards are carried along to make for easy recognition.

\subsection{Sealing and Seizure}

This methodology involves sealing up any area or site which has been, will be or is being used directly or indirectly for the purpose of depositing or dumping any harmful wastes.

Also, the authorized law enforcement agent under some statutes ${ }^{45}$ is empowered to seize any item or substance which he has any reason to believe has been used in the commission of a crime under the particular decree. However, seizure could be in the public interest in order to forestall further pollution by putting the offending "item or substance" out of circulation (Okorodudu-Fubara, 1998).

\subsection{Arrest}

This is the most common of all the enforcement measures. It is provided for in all states and local governments that deal with environmental protection. The authorized government agent is given the power to arrest any person who he has a reason to believe has committed an offence under the said law.

\subsection{Permit, Licence and Certificate}

These serve as the most effective measures of enforcement of environmental laws. Environmental statutes and regulations provide for issuing permits, licence and certificates upon application and satisfaction of laid down conditions prior to the issue. These permits, licence and certificates are used by the government as monitoring devies to regulate the activities which are potential sources of environmental pollution. Therefore the issuance carries with it an understanding that the holder of the permit, licence or certificate will forfeit such upon the breach of the regulations, statute or any of the laid down conditions specified on such permit, licence or certificate.

\subsection{Criminal Prosecution}

This is a viable method of enforcing environmental laws. Violators of environmental laws are charged to court and if found guilty, convicted to court. The agency (NESREA) has the power to convict violators of the various categories of law. For instance, Section 22 of NESREA, 2007; anyone who commits the offence of noise pollution shall on conviction be liable to a fine not exceeding N50,000 or to imprisonment for a term not exceeding one year or to both.

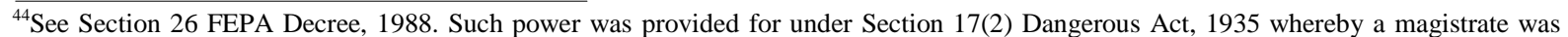
empowered to issue search warrant in justifiable circumstance authorizing the police officer named therein to enter any premises or vessel by force and search the premises and vessel and person found therein. Also Section 10 of the Harmful Waste (Special Criminal Provision etc.) Decree, 2004 has a similar provision that any police officer may without warrant enter and search any land, building or carrier, including aircraft, vehicle, container or any other things whatsoever which he reason to believe is related to the commission of a crime under the dec.

${ }^{45}$ See FEPA Decree, 1988.
} 
Section 1(2) of the Harmful Wastes (Special Criminal Provision) Decree, 1988 makes it clear that any person who engages in any of the prohibited activities (without lawful authority) shall be guilty of a crime under the decree and the offender shall on conviction be sentenced to imprisonment for life. This is a very potent enforcement strategy ${ }^{46}$.

\subsection{Civil Penalties}

This involves the payment of damages or costs as a result of the violation of any of the environmental protection laws in Nigeria. Under NESREA ${ }^{47}$, where an owner or operator of any vessel or onshore or offshore facility responsible for the discharge of hazardous substance contrary to Section 20, he will be in addition to the criminal penalty prescribed in that section be liable for: 1 ) the cost of removal of the hazardous substance as well as any cost incurred by the Government or its agencies in the restoration or replacement of natural resources damaged or destroyed as a result of the discharge; and 2) costs of third parties in the form of reparation, restoration, restitution or compensation as may be determined by NESREA from time to time (Okorodudu-Fubara, 1998).

\section{Functions of Environmental Law Enforcement Agencies in Nigeria}

There are many environmental law enforcement agencies that assist the implementation of environmental laws in Nigeria. Some of these are explained below:

\subsection{National Environmental Standards and Regulations Enforcement Agency (NESREA)}

This is the major enforcement agency in Nigeria. It is also referred to as "the agency"48. The agency is required by law to take charge of the protection and development of the environmental technology, including initiation of policy in relation to environmental research and technology and specifically to advise the Federal Government on natural environmental policies and priorities and on scientific and technological activities affecting the environment. It is the enforcement agency for environmental standards, regulations, rules, laws, policies and guidelines.

It is empowered to enforce compliance with laws, guidelines, policies and standards on environmental matters, carry out activities necessary for the performance of its functions, prohibits processes and use of equipment or technology that undermine environmental quality, conduct field follow-up of compliance with set standards and take procedures prescribed by law against any violator, conduct public investigations on pollution and the degradation of natural resources, develop environmental monitoring networks and do such other things other than in the oil and gas sector as are necessary for the efficient performance of the functions of the Agency.

\subsection{National Oil Spill Detection and Response Agency (NOSDRA)}

The Federal Government established this agency as an institutional framework to implement the National oil spill contingency plan which is a blueprint/manual for checking oil spill through, containment, recovery and remediation/restoration.

\subsection{National Water Resources Institute (NWRI)}

This institute monitors the pollution of water and enforces the treatment of drinking water.

\subsection{Nigeria Maritime Administration and Safety Agency (NIMASA)}

This agency is committed to marine pollution and prevention control, search and rescue, sabotage enforcement, training and certification of seafarers.

\subsection{National Emergency Management Agency (NEMA)}

This agency partners with NESREA and National Orientation Agency (NOA) in managing disasters and flood in

\footnotetext{
${ }^{46}$ See also Abia State Environmental Protection agency Edict, 1994.

${ }^{47}$ See Section 27, National Environmental Standards and Regulation Enforcement Agency (NESREA) Act, 2007.

${ }^{48}$ See Section 1 of the National Environmental Standards and Regulations Enforcement Agency (Establishment) Act, 2007.
} 
Nigeria.

\subsection{National Orientation Agency (NOA)}

The National Orientation Agency helps in ensuring that Federal Government environmental programmes and policies are better understood by the general public. It enlightens the public on the pros and cons of environmental policies of the Federal Government and interprets these policies in the language best understood by them.

\subsection{National Agency for Food and Drug Administration and Control (NAFDAC) National}

Agency for Food and Drug Administration and Control (NAFDAC) is under the Federal Ministry of Health and it issues permits to industries for importation of foods, cosmetic and chemicals.

\subsection{The Nigerian Police}

Nigerian Police Officers are empowered to ensure, monitor and enforce the laws on environmental activities in Nigeria particularly with respect to the Harmful Waste $\mathrm{Act}^{49}$. They can conduct a warrantless search on any building, land, carrier, aircraft or any other thing whatsoever which they have reasons to believe is related to the commission of a crime under this act. As a result of this, the Nigerian police officers cooperate with NESREA to carry out its mandate to enforce environmental laws ${ }^{50}$.

\subsection{State Environmental Protection Agency/Local Government Environmental Protection Agency}

The federating units constitute the environmental theatre where the "substantial degree of activities" are conducted. They play significant roles in the enforcement of environmental laws. As stated earlier, FEPA (now NESREA $^{51}$ ) is thus the supreme reference authority in environmental matters in Nigeria although state and local government authorities and institutions including their environmental departments are still expected to play their traditional role of maintaining and enforcing standards as well as fixing penalties charges, taxes and incentives to achieve certain environmental goals.

With the setting up of FEPA, the States Environmental Protection Agencies (SEPAS) were set up. These were complemented by the Local Governments (LGAs) Environmental Protection Agencies.

\subsection{The Court}

Under the Nigerian legal system, the judiciary interprets the law thus the judiciary breathes life into the law to ensure compliance. Lord Denning succinctly captured the reality when he said (Chianu, 2007):

In theory the judges do not make law, they merely expound it.

But as no one knows what the law is until the judges expound it, it follows that they make it.

Class actions by a group or a community of people pursuing environmental claims can be embarked on in the court of law. These actions are common in the oil and gas industries where the industries pollute the land, air and water of a particular community and they seek redress in court. Nigerian courts have awarded special and general damages in actions for damages arising from environmental pollution.

In the protection of the environment, there are few cases where the judges have boldly lent their heavy weight in this important task. Issues of jurisdiction and locus standi in environmental litigation have contributed to this.

For instance, the issue of jurisdiction was a problem and challenge for the Supreme court in the case of Shell Petroleum Development Company (Nigeria) Ltd v Abel Isaiah ${ }^{52}$ where there was an Oil spillage that polluted the swamp of the plaintiff/respondent. At the time, it was only the Federal High Court that had jurisdiction ${ }^{53}$ over oil spillage cases. The case was however within the exclusive jurisdiction of the Federal High Court. The Supreme

\footnotetext{
${ }^{49}$ See Section 10 of the Harmful Waste (Special Criminal Provisions) Act, 1990.

50 "Nesrea Partners Police to Prosecute Environmental Crimes in the FCT” Sunday Trust (Nigeria February 2010)

$<$ http://www.sundaytrust.com.ng/.../11201-nesrea-partners-police-to-prosecute-environment> accessed on 29 January 2014.

${ }^{51}$ National Environmental Standards and Regulations Enforcement Agency (Establishment) Act, 2007.

${ }^{52}$ (2001) 5 S.C. (pt. 11) 1.

${ }^{53}$ See Section 230(1) of the Constitution (Suspension and Modification) Decree No. 107 of 1993.
} 
court had to deliberate on the Court of Appeal's decision that the High Court jurisdiction's is right (Ladan, 2007).

In Jonah Gbemre v Shell PDC Ltd and Ors ${ }^{54}$ The justice of the Federal High court in Nigeria granted leave to the defendant to institute an action in the representative capacity and to apply for an order enforcing the fundamental rights to life and human dignity as provided by the constitution ${ }^{55}$ and reinforce in the African Charter on Human and People's Right ${ }^{56}$. The court held that these constitutionally guaranteed rights inevitably include the rights to clean, poison and pollution-free healthy environment. The judge's order restrained the respondents from further gas flaring and to take immediate steps to stop the further flaring of gas in the community (Ladan, 2007).

All these point to the fact that the courts are efficient in the enforcement of environmental law.

\section{The Deficiencies and Challenges of Environmental Law Enforcement}

There are inadequate policies operative in Nigeria for coordinating and monitoring the relationship between environmental management and sustainable development. This leads to poor enforcement of the environmental protection legislation in Nigeria. An ineffective enforcement strategy is one of the environmental law enforcement challenges. Most of the enforcement strategies and mechanisms are poor and not being implemented. For instance, the mechanism for collection and management of environmental statistics of facilities and service providers including waste transporters, waste vendors, landfills areas, companies effluent emission data, carbon footprints, sewage treatment plants and other recycling companies are neither developed nor implemented ${ }^{57}$.

The focus and target of environmental law enforcement is also a problem. It is ridiculous to have the Agency arresting goats instead of human beings for violating environmental laws. On the $9^{\text {th }}$ of January 2013, five goats were arrested in Osun State, Nigeria by police officers for violating environmental protection law by roaming around the residential area of Oshogbo instead of being caged by their owners ${ }^{58}$.

Fund is also a challenge. To meet their obligations and be able to perform their functions effectively, the agencies must be financially viable (Okorodudu-Fubara, 1998). Lessons from the experience show that Local Governments are devoid of the requisite human and material resources to undertake environmental management as a result of inadequate funding. This however affects effective environmental law enforcement (Ogbuigwe, 1996). In Lagos State for example, except for the Lagos Pollution Fund, all revenues from fines go to the general government revenues and not to State Environmental Protection Agency. Without direct gain from enforcement throught increased agency revenue, there is still little incentive to pursue enforcement aggressively. Local Government were often staved of funds or could not attract the required high-level manpower, they are therefore under staffed. They could neither attain the sophisticated expensive equipment nor meet the demands of varied responsibilities.

Threats from powerful individuals and groups challenge effective environmental law enforcement. Powerful individuals and groups who own industries become vicious and formidable. An example is the interference of the Federal Government in functions exclusive to NESREA. The Federal Government in May 2012, barred NESREA from sealing telecoms Mast ${ }^{59}$.

Corruption and bad governance prevalent in the country also affect the enforcement of environmental laws. Some owners and operators of the facilities fight back NESREA using blackmail and/or intimidation. Some pose as officers of the Agency to harass and threaten owners/operators of facilities with the aim of exhorting money from them in exchange of lenient sanctions or waiver of penalties (Ladan, 1998).

Another major challenge of enforcement of environmental laws is lack of modern technology. Till date, officers monitoring the environment do not have the effective modern equipment to enhance monitoring of some of the environmental problems.

Low-level constitutional provision for environmental protection is a deficiency (Nwafor, 2006). The provision

\footnotetext{
${ }^{54}(2005)$ Suit No. FHC/B/CS/53/05.

${ }^{55}$ See Section 33(1) and 34(1) of the 1999 Constitution of the Federal Republic of Nigeria.

${ }^{56}$ See African Charter on Human and People’s Right, Cap.A9, LFN 2004.

57"Addressing the Many Challenges of NESREA" <http://www.nigerdeltaheartbeat.wix.com> accessed on 21 January 2014.

58،"Five Goats Arrested in Osun” The Sun Newspaper (Nigeria 12 January 2013) < http://www.sunnewsonline.com> accessed on 21 January 2014.

59"Federal Government Bars NESREA from Sealing Telecoms Masts” This Day Live (Nigeria May 2012)

$<$ http://www.thisdaylive.com/articles/fg-bars-nesrea-from-sealing-telecoms-masts/116746/> accessed on 29 January 2014.
} 
for and the emphasis laid on environmental protection and management by the Nigerian constitution ${ }^{60}$ are low compared to the rate and stage of environmental degradation in the country.

The 1999 constitution contains very few provisions enabling citizens to enforce their fundamental rights to a clean environment except that such right might not be justiceable. This has led to the non-challant attitude of most citizens towards the preservation and the protection of the environment.

NESREA, the major agency of enforcement of environmental laws does not have enforcement powers over the oil and gas sector. As a result of this, NESREA does not have powers to enforce laws on matters of pollution, exploration and exploitation of petroleum and natural gas. This hinders environmental justice.

There are also role conflicts in environmental management. No clear cut delineation of functions to the existing agencies. This leads to role conflicts between them. For example, certain functions and powers, until the creation of FEPA, were exercised by six other ministries/agencies that had responsibilities of environmental management (Nwafor, 2006). The discordance in the relationship among the tiers of government, limits the effectiveness in carrying out their environmental protection, monitoring and enforcement.

Undue adherence to legalism by the courts is also a challenge. One of the major problems of enforcement of environmental laws in Nigeria is the issue of locus standi. Individuals don't have environmental rights (locus standi) to pursue their environmental related problems in the court of law In order to claim the infringement of a particular environmental right or law, the litigant must be competent to commence an action and must show that he has suffered great loss or harm from the actions of the defendant.

However, in Nigeria, matters relating to environmental civil litigation are far from being liberalized by our courts and this hinders private individuals from participation in the enforcement of environmental protection legislation (Nwafor, 2006).

Limited number of experts in the environmental field to give evidence also frustrates environmental litigation in Nigeria $^{61}$.

It is also worthy to note that victims of environmental pollution face the problem of proving their case before the court of law. For example, in the case of Shell Petroleum Development Company Nig Ltd v Chief G.B.A Tiebo VII \& $\mathrm{Ors}^{62}$ where the trial court awarded damages for the loss of raffia palms and drinking water as a result of the crude oil spill on the land, creeks and lakes of the plaintiff. The defendants appealed to the court of appeal and further to the Supreme Court on whether it was proper for the court below to award special damages when there was no sufficient proof. The Supreme Court held that in proving special damages, what was required was a strict proof.

The absence of mandatory disclosure of information by industries which hinders monitoring. The absence of mandatory disclosure of information by industries and operators of facilities whose operations are likely to cause pollution is another deficiency on the enforcement of environmental laws. There is no legal framework for the industries; compelling them to abide by the requirements for compliance in respect of pollution abatement standards.

The industries conceal or select the interpretation of quantitative or qualitative information about impacts.

It must be stated that NESREA acts by the limited environmental information available, the range, nature and diversity of information required as well as the scope of work itself.

In Nigeria, there is no legal arrangement which guarantees public access to information on compliance monitoring of industries and facilities. However, as the number of legislative requirements increases, so is the need to promote public awareness of environmental laws and regulations at national and local levels through training and information transfer on Environmental Impact Enforcement (EIA) (Nwafor, 2006).

A highly generalized system of classification of industries which omits some industries in the classification. This poses difficulties in applying environmental impact assessment guidelines guidelines to those industries which have not been captured.

Poor communication among the internal departments of Federal Ministry of Environment to the extent that the department may be unaware of what other departments are doing, surprising lack of knowledge of the general legislation covering the environment and lack of clarity about the roles of the federal and state ministries and the State Environmental Protection agency in monitoring and enforcement of Federal and State environmental laws and regulations.

\footnotetext{
${ }^{60}$ See Sections 20 and 6(6) (c) of the 1999 Constitution of the Federal Republic of Nigeria.

${ }^{61}$ See Seismographs Services V Benedict Onokposa (1972) 4 SC 123.

${ }^{62}(1976) 4$ N.W.L.R (Pt 445) 657.
} 
The search power of the officers of NESREA is deficient in making provisions for an order of court before a search can be conducted on any vessel or premises. This causes the arbitrary exercise of powers by the officers.

Failure to state clearly the punishment and penalties for violating these guidelines and regulations which creates the impression that compliance is optional.

\section{Suggested Reforms for the Enforcement of Environmental Laws in Nigeria}

The challenges of enforcement of environmental law are universal. Several countries have attempted in their own ways to make and review laws to promote an effective enforcement of environmental laws ${ }^{63}$.

For instance, China had just amended its environmental protection law enacted in 1989. Some of the problems of the environmental laws are superficial enforcement of environmental mechanisms, the lacuna in the provision of rules that effectively ensure implementation, low fines to deter polluters, lax investigation and delayed punishment of illegal activities, unavailability of adequate compensation for pollution victims, lack of authority within relevant environmental protection administrations amongst others.

There are also many environmental management mechanisms within China ${ }^{64}$ but they have not been fully implemented. The agencies responsible for drafting reports tend to falsify them in order to satisfy the construction entities. For instance in a report, the real distance between a proposed plant and a residential district was 20 metres while the Environmental Impact Assessment report stated the distance at 400 meters; the construction was approved and later caused severe pollution ${ }^{65}$.

Consequently, lax enforcement is one reason small enterprises responsible for environmental harm remain active and perpetuate new pollution emissions. However with the amendment, stricter punishments for polluters are provided for and also greater powers for environmental authorities.

Environmental enforcement and compliance is also a critical issue in American countries especially Central America. Most of the laws are not clear, flexible and do not have effective mechanisms for achieving their stated goals. Some of the major limitations are lack of political will, inefficient legal frameworks that do not address environmental issues in an appropriate manner, failure to include environmental issues in National policy plans and planning processes; and lack of financial and human resources.

Positive aspects of the environmental law enforcement of these countries can be emulated and embedded into our laws. China's environmental law gives the local government responsibility for environmental quality and also gives awards to units and individuals that have made outstanding achievements in protecting the environment; this could be used as a model for local governments in Nigeria ${ }^{66}$. Other suggested environmental enforcement reforms include:

\subsection{Environmental Law Awareness}

Awareness should be made all around the country, in every state and local government areas about the dangers and the effects of the pollution of the environment. The Government and the various NOA should educate people on the importance of keeping a sane environment and the positive effects on the development of the Nigerian economy.

Advertisements should be made via the media to inform people all over the country of the environmental problems prevalent in the country and the ways to mitigate most of the problems. Individuals and communities should also be encouraged to participate in environmental improvements efforts.

Acceptable standards of operation and compliance should be established and published online for the interest of the public and for easy access ${ }^{67}$.

\footnotetext{
${ }^{63}$ For instance, Chinese legislators amended the country's environmental protection law on the $24^{\text {th }}$ April 2014; this amendment will apportion greater powers to environmental authorities and harsher punishments for polluters. See

$<$ http://www.nytimes.com/.../china-legislature-toughens-environmental-law.html> accessed on 14 May 2014.

${ }^{64}$ These include various precautionary approaches to prevent pollution, regulations governing the operation of various facilities, environmental recovery institutions and enforcement obligations of environmental protection supervisors.

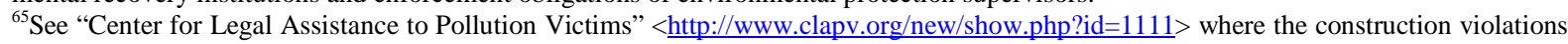
of a coke plant were described. See also Wang C., Chinese Environmental Law Enforcement: Current Deficiencies and Suggested Reforms" $<$ http//:www.vjel.vermontlaw.edu/files/.../Chinese-environmental-law-enforcement.pdf> accessed on 15 April 2014.

${ }^{66}$ Article 8 - 9, Environmental Protection Law of the People's Republic of China, 1989. Chinese legislators passed an amendment to the country's environmental protection law on the $24^{\text {th }}$ April 2014; this amendment promises greater powers for environmental authorities and harsher punishments for polluters. <http://www.china.org.cn/english/environment/34152.htm> accessed on 14 May 2014.

67“Addressing the Many Challenges of NESREA" <http://www.nigerdeltaheartbeat.wix.com> accessed on 21 January 2014.
} 
National environmental policies should also be coordinated at the community level for effective implementation, monitoring, evaluation and improvement.

\subsection{Training}

The Government should try as much as possible to equip its enforcement agencies on how to ensure the effective enforcements of the environmental laws in existence.

All project programmes predicted to have a significant negative impact on the environment will require an effective environmental monitoring programme, especially where environmental standards have been set. Therefore officers of the agencies should be trained for effective enforcement.

\subsection{Effective Environmental Monitoring}

Monitoring the environment involves checking, observing and recording information about the environment to prevent it from being destroyed by man's activities especially those involving sophisticated technology, to plan for future exploitation of its resources and to control the unpleasant effects of environmental mismanagement (Ogidiolu, 2007).

Environmental monitoring instruments should be made available for effective enforcement. This will enhance the collection, analysis and distribution of relevant data to environmental impact assessment, policy analysis and environmental monitoring units within the States and Local Governments.

\subsection{Fund}

More funds should be allocated by the Government at all levels to enhance the execution of projects geared towards the improvement of the environment. As stated earlier, lessons from the experience show that Local Governments are devoid of the requisite human and material resources to undertake environmental management. These bye laws from the local government are neither well articulated nor programme instruments designed to protect the environment.

\subsection{Stiffer Punishments of Environmental Offences}

The attitude of the court and the liabilities of those that violate environmental laws are also important in the enforcement of environmental laws. The attitude of courts in their various judgments towards environmental justice should be positive. Just orders should be made to remedy the damages done to the physical environment of private individuals who seek redress in the law court. This would enhance enforcement of the set rules and regulations due to the fact that people would be subjected to obey the regulations and guidelines of environmental laws as a result of the harsh penalties for those found guilty of environmental offences.

\subsection{Submission of Periodic Reports}

The State Government should ensure the preparation of periodic reports on the state of the environment in each State or community for submission to the Ministry of Environment (Aina, 1992). This will enhance the enforcement methodologies and new strategies are initiated for effective monitoring and management of the environment. The state of the environment needs to be consistently monitored for sustainable development to be guaranteed.

\subsection{Private Litigation}

This is referred to as "Concerned Citizens Action" to enforce environmental laws and regulations in the face of threatening actions by private or public organizations which are detrimental to the environment. The "polluter" must pay for his actions. This is a viable tool for the enforcement of environmental laws to give the environment its priority in the consciousness of the citizenry. The average citizen should have a proprietary interest in the human environment, such that he feels a personal responsibility to protect and defend that interest (Nwafor, 2006).

A citizen of the country can institute an action agent of any private or public organizations who threatens to 
act or acts in a way that is detrimental to the environment. Access to court or administrative tribunal is a human right of an aggrieved person (Ladan, 2007). This would enhance the enforcement of environmental laws in the country.

\subsection{Effective Access to Justice}

Legal aid scheme should be provided for those victims that cannot afford the high cost of litigation. The citizens should have equal and effective access to justice.

\subsection{Job Opportunities}

Job opportunities should be created for the citizens of the country in order to alleviate poverty rate in the country. Most of the environmental problems arise as a result of poverty; lack of alternative source of energy to people who engage in felling economic trees for sustenance, hunting wild animals, engaging in excessive fishing activities thus doing great harm to the environment.

The more availability of jobs will reduce the rate of environmental degradation thus help boost sustainable development in Nigeria.

\subsection{Quick Response to Environmental Emergencies}

There should be quick response to environmental emergencies in the country to prevent the occurrence of worst case scenarios. Prevention is always better than cure.

\subsection{Establishment of Environmental Courts}

Just like there are National Industrial Courts in the country, environmental courts that would entertain environmental matters should be established for better enforcement of environmental laws in the country. This would ensure quick response to the needs of the environment, popularize environmental laws and aid enforcement of those laws.

\section{Conclusions}

It is trite to say that most of the environmental problems in Nigeria are as a result of the lackadaisical attitude of government towards the enforcement of environmental laws.

The Pre-1988 environmental laws lacked adequate policies for coordinating the environmental laws and making them effective. There were also no mechanisms for collection and management of environmental statistics, no waste transporters, companies' emission data and other anti-pollution equipment. The major concern of the government was environmental sanitation ${ }^{68}$ and not eradication of environmental pollution, desertification, deforestation, use of pesticides and other core environmental problems. These enforcement deficiencies however prevented an effective enforcement of the environmental laws thus the lack of focus on the environmental problems inherent in the country further aggravated the environmental problems in Nigeria.

However, the Post-1988 environmental laws addressed most of the environmental problems in Nigeria. This started with the discovery of the hazardous waste in 1988 dumped by an Italian in the former Bendel State of Nigeria. The discovery propelled the Federal Government to reassess the general state of its environmental regulation in Nigeria and promulgate both the Hazardous Waste Act and the Federal Environmental Protection Agency Act which prevent prohibits the dumping of harmful wastes in Nigeria and promote sustainable development of the environment and its natural resources respectively. These acts were followed by several other acts for the enforcement of environmental laws ${ }^{69}$.

It is pertinent to note that most of these environmental laws are written on paper but yet to be implemented as a result of the challenges and deficiencies of enforcement. The enforcement agencies; the police, the court, the state and local government lack effective enforcement strategies for the implementation of the laws.

The agencies are not financially viable to meet their obligations and perform their functions effectively. Nigeria lacks modern technology and standard equipment for monitoring the environment to prevent pollution.

\footnotetext{
${ }^{68}$ Public Health Act, 1917.

${ }^{69}$ Laws of the Federation of Nigeria 2004.
} 
Corruption has eaten deep in the society to the extent that pseudo officers harass and threaten violators of environmental laws with the aim of extorting money from them, and also the allocated fund for the implementation of environmental laws are shared between officers of the agencies for their personal use.

The punishments for violating the laws are too lenient. For example, under the Petroleum Refining Regulation $^{70}$ whoever pollutes the environment will pay a fine of One Hundred Naira Only or imprisoned for six months. As a result of this, people are not subjected to obey the regulations and guidelines of the environmental laws.

It is recommended that the Federal, State and Local Government should all reassert a stringent enforcement of environmental laws in Nigeria with the aim of punishing adequately all defaulting firms.

NESREA; the major environmental law enforcement agency in Nigeria should be restructured giving it more authority on all environmental law enforcement efforts including the environmental permitting and monitoring of all new and existing projects including the approval of strategic environmental impact assessment ${ }^{71}$.

All States and Local Governments should have their independent supervisory and monitoring bodies that will be responsible for the enforcement of environmental law and awards should be given to the units and individuals that have made outstanding achievements in protecting and improving the environment. China's environmental law gives the local government responsibility for environmental quality and also gives awards to units and individuals that have made outstanding achievements in protecting the environment; this could be used as a model for local governments in Nigeria ${ }^{72}$.

All existing environmental laws should be reviewed so as to fill in the existing lacuna and loopholes which industries, companies and firms have taken advantage of.

Funds for the creation of awareness, purchase of equipments and other necessities should be disbursed and channeled to the appropriate quarters they will be needed for effective environmental management and enforcement of environmental laws.

On the whole, environmental courts may be established to entertain environmental matters. This will ensure quick response to the needs of the environment, promote rapid awareness of the needs of environmental laws and aid enforcement of these laws.

\section{References}

Adelagan, J. A. (2004). The History of Environmental Policy of Water Sources in Nigeria (1960-2004): The Way Forward. http://www.userpage.fu-berlin.de/flu/akumeu-ibc2004/download

Aina, E. O. A. (1992). Keynote Address-Nigeria’s Environmental Balance Sheet. In E. O. A. Aina, \& N. O. Adedipe (Eds.), Environmental Consciousness For Nigerian Development (p. 3), Lagos: Federal Environmental Protection Agency.

Chianu, E. (2007). The Horse and Ass Yorked: Legal Principle to Aid the Weak in a World of unequal. Inaugural Lectures Series 91, Benin City: University of Benin.

Egbon, P. C., \& Behrooz, M. (1996). Environmental Policy Planning. National Centre for Economic Management and Administration.

Ijaiya, H. O. (2013). The Legal Framework for Solid Waste Disposal and Management in Kwara State, Nigeria. http://www.scirp.org/journal/paperinformation.asp\&?paperID=39722

Ladan, M. T. (1998). Law of Environmental Protection. Caltop Publications Nigeria Limited.

Ladan, M. T. (2007). Judicial Approach to Environmental Litigation in Nigeria. Paper Presented at a 4-Day Workshop on Environmental Law, Nigeria.

Ladan, M. T. (2009). Law, Cases and Policies on Energy, Mineral Resources, Climate Change, Environment, Water, Maritime and Human Rights in Nigeria. Zaria: Ahmadu Bello University Press.

Nwafor, J. C. (2006). Environmental Impact Assessment for Sustainable Development: The Nigerian Perspective (1st ed.). EDPCA Publishers.

Ogbuigwe, A. (1996). Report on the Review of Environmental Protection Agency in Enugu State. Anpez Environmental Law Centre Port Harcourt for Enugu State Environmental Protection Agency, Enugu.

\footnotetext{
${ }^{70}$ See Section 45 of the Petroleum Act, Cap P10 Laws of the Federation of Nigeria, 2004.

71“"Addressing the Many Challenges of NESREA” $<$ http://www.nigerdeltaheartbeat.wix.com> accessed on 21 January 2014.

${ }^{72}$ Article 8 - 9, Environmental Protection Law of the People’s Republic of China, 1989. Chinese legislators passed an amendment to the country's environmental protection law on the $24^{\text {th }}$ April 2014; this amendment promises greater powers for environmental authorities and harsher punishments for polluters. <http://www.china.org.cn/english/environment/34152.htm> accessed on 14 May 2014.
} 
Ogidiolu, A., \& Balogun, F. T. (2000). Techniques of Environmental Monitoring and Management: In Jimoh \& Ifabiyi (Eds.), Contemporary Issues in Environmental Studies (p. 71), Haytee Press \& Publishing Co. Ltd.

Okorodudu-Fubara, M. T. (1998). Law of Environmental Protection. Caltop Publications Nigeria Limited.

Otu, N. E. (2010). An Evaluation of the National Environmental Standards and Regulations Enforcement Agency (Establishment) Act. A Paper Presented at the Abia State College of Postgraduate Studies, Faculty of Law, Nigeria. 
Scientific Research Publishing (SCIRP) is one of the largest Open Access journal publishers. It is currently publishing more than 200 open access, online, peer-reviewed journals covering a wide range of academic disciplines. SCIRP serves the worldwide academic communities and contributes to the progress and application of science with its publication.

Other selected journals from SCIRP are listed as below. Submit your manuscript to us via either submit@scirp.org or Online Submission Portal.
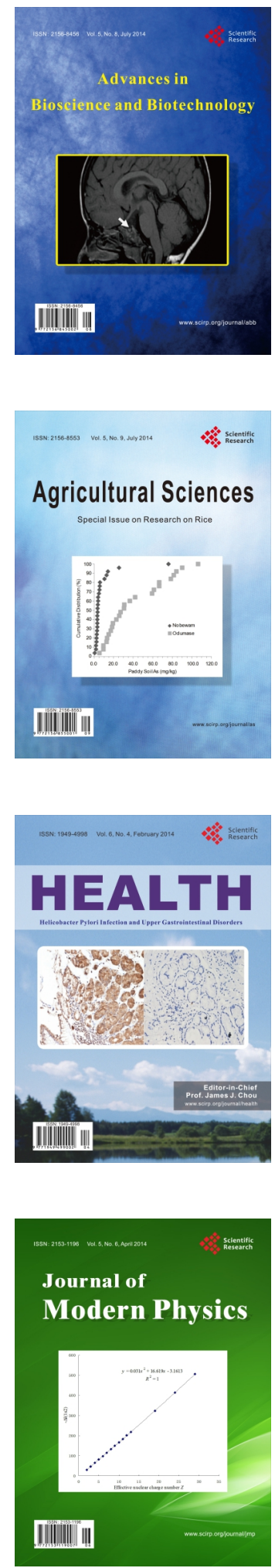
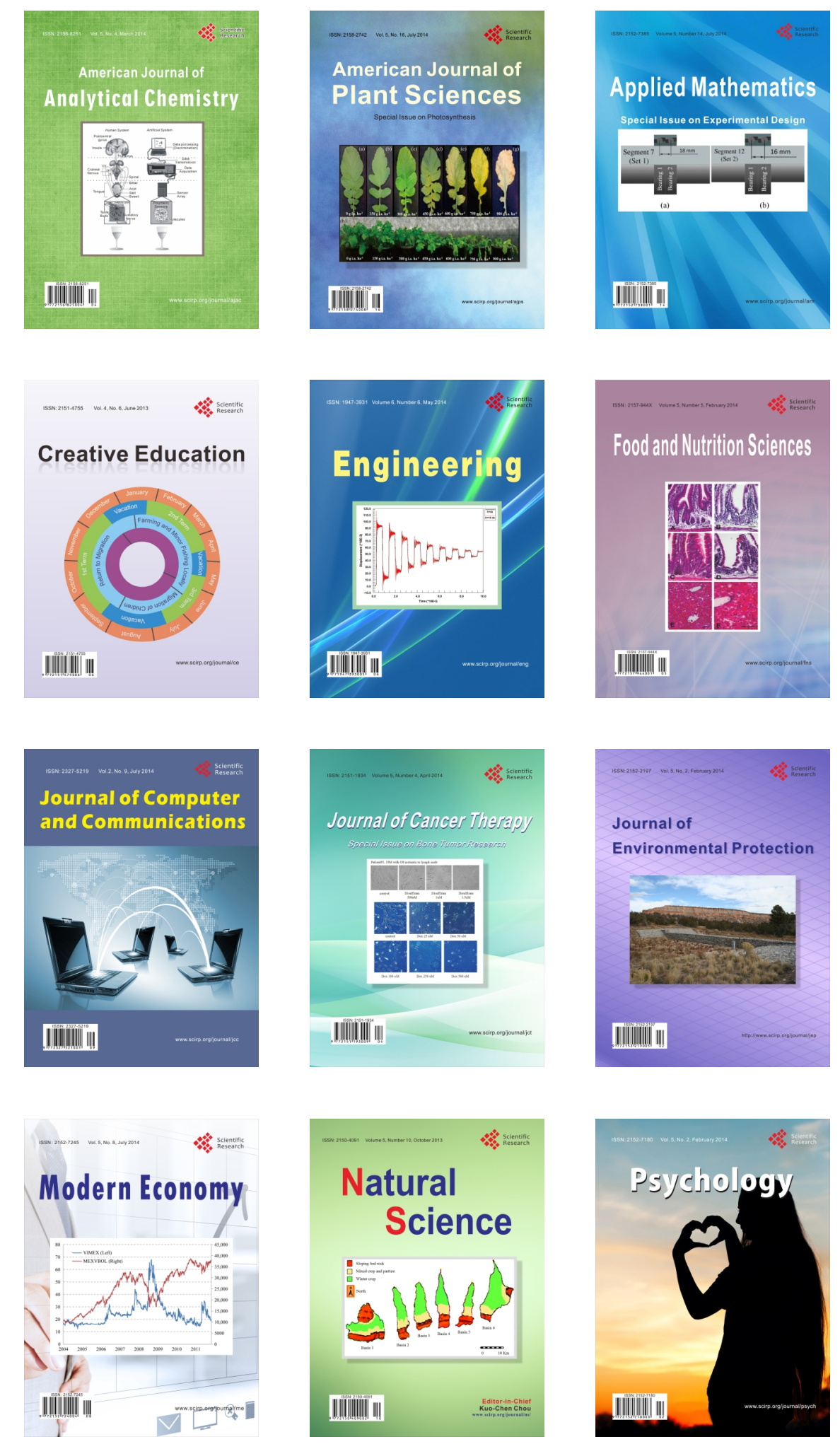